\title{
Paleoparasitology: the origin of human parasites
}

\author{
Paleoparasitologia: a origem dos parasitas humanos \\ Adauto Araújo', Karl Reinhard², Luiz Fernando Ferreira', Elisa Pucu', Pedro Paulo Chieffi
}

\begin{abstract}
Parasitism is composed by three subsystems: the parasite, the host, and the environment. There are no organisms that cannot be parasitized. The relationship between a parasite and its host species most of the time do not result in damage or disease to the host. However, in a parasitic disease the presence of a given parasite is always necessary, at least in a given moment of the infection. Some parasite species that infect humans were inherited from pre-hominids, and were shared with other phylogenetically close host species, but other parasite species were acquired from the environment as humans evolved. Human migration spread inherited parasites throughout the globe. To recover and trace the origin and evolution of infectious diseases, paleoparasitology was created. Paleoparasitology is the study of parasites in ancient material, which provided new information on the evolution, paleoepidemiology, ecology and phylogenetics of infectious diseases.
\end{abstract}

Keywords: paleoparasitology, paleoepidemiology, parasitism, human parasites, ancient infection diseases.

\section{RESUMO}

O parasitismo é composto por três subsistemas: o parasito, o hospedeiro e meio ambiente. Não existe organismo que não possa ser parasitado. A relação entre um parasito e suas espécies de hospedeiro não resulta, na maior parte das vezes, em dano ou doença ao hospedeiro. Entretanto, numa doença parasitária, a presença de um determinado parasito é sempre necessária, pelo menos em um determinado momento da infecção. Algumas espécies de parasitos que infectam humanos foram herdados dos pré-hominídeos, e foram compartilhados com outras espécies de hospedeiro filogeneticamente próximas, mas outras espécies foram adquiridas pelo meio ambiente à medida que os humanos se desenvolveram. As migrações humanas espalharam os parasitos adquiridos por todo o mundo. Para recuperar e traçar a origem e evolução das doenças infecciosas foi criada a paleoparasitologia. Paleoparasitologia é o estudo dos parasitos em materiais antigos, que trouxe novas informações na evolução, paleoepidemiologia, ecologia e filogenética das doenças infecciosas.

Palavras-Chave: paleoparasitologia, paleoepidemiologia, parasitismo, parasitos humanos, doenças infecciosas antigas.

\section{Parasites, parasitism, and infectious disease}

There is a tenuous limit between health and disease. Regarding infectious diseases, people may be infected by a parasite throughout their life without any symptom. A slight change in the relationship of the system host-parasite-environment may change the balance, and so disease appears.

A parasite may be defined as an organism, or a genetic sequence able to reproduce itself, that finds its ecological niche in another organism, or in another genetic sequence ${ }^{1}$. Therefore, essentially parasitism is an ecological phenomenon.

In some regions of the American continent there are many people infected by Trypanosoma cruzi. However, in most individuals the infection is called "indeterminate", i.e. without any symptoms. Individuals may live asymptomatic throughout their lives, but others may suffer from severe disease. The most known case was Berenice, a girl in which Carlos Chagas discovered the parasite. She lived all her life infected with the parasite showing no symptoms, dying of other causes many years after the death of Carlos Chagas.

Parasitism is the phenomenon in which a complex system composed by three subsystems are involved: the parasite, the host, and the environment ${ }^{2}$. The system evolved together, but changes in any subsystem may cause disturbances and the disease takes place. There are no organisms without parasites. Parasitism is a phenomenon that appeared at the same moment as life emerged on Earth. Since then, parasites and hosts evolved and has provided to the biodiversity, as is

${ }^{1}$ Fundação Oswaldo Cruz, Rio de Janeiro RJ, Brasil;

${ }^{2}$ School of Natural Resource Sciences, University of Nebraska, Lincoln, USA;

${ }^{3}$ Instituto de Medicina Tropical de São Paulo, Faculdade de Ciências Médicas da Santa Casa de São Paulo, São Paulo SP, Brasil.

Correspondence: E-mail:adauto@ensp.fiocruz.br

Funding: This study was supported by FAPERJ (Fundação Carlos Chagas Filho de Apoio à Pesquisa do Estado do Rio de Janeiro), CNPq (Conselho Nacional de Desenvolvimento Científico e Tecnológico), and CAPES (Ciência sem Fronteiras). 
presently known ${ }^{1}$. This is an association between organisms. Therefore, parasitism as a phenomenon is part of nature and must be studied as an aspect of ecology ${ }^{3}$.

Host-parasite relationships most of the time do not result in disease. The presence of a parasite in a given host does not always result in damage for the individual. However, in a parasitic disease the presence of a given parasite is always necessary, at least in a given moment of the infection ${ }^{2}$. Snakes infected by Entamoeba invadens may exemplify this. This amoeba species lives in the intestinal tract of snakes without causing any damage. However, when changes in temperature are experimentally induced, the parasite invades tissues causing lesions and sometimes the death of the host ${ }^{4}$.

The three variables that compose infectious diseases, the host, the parasite, and the environment are in a constant state of flux $x^{5}$. They can change according to any variation in the components. Therefore, new diseases appear, others are altered, and some may disappear completely ${ }^{5}$. Human parasites and human infectious diseases follow these rules. The first hominids in Africa were hosts for some species of parasites. Some of these parasites were inherited from pre-hominids, and were shared with other phylogenetically close host species. But other parasite species were acquired from the environment as hominids evolved ${ }^{6}$. These two lines for the origin of human parasites are called phylogenetic and ecologic lines, respectively?

In such a peculiar host as humans, different opportunities were offered to parasites. Humans have spread to every part of the globe, carrying inherited, or heirloom parasites to different biomes occupied and transformed by them, whenever environmental conditions allowed the life cycle of the parasite $^{7}$. On the other hand, new parasites were acquired in the new territories due to the density growth of the population and new technologies created by humans. As well as parasitic infections, infectious diseases have also been evolving from the earliest days of human host-parasite relationships ${ }^{6}$. Human migrations around the world, the emergence of agriculture, the domestication of animals, and the increase in populations together with urbanization, favored changes in the pathoecology of infectious diseases ${ }^{8}$.

Cockburn $^{6}$ called attention to the steps of human biological and social evolution, highlighting the role of demography and the spread of disease. He observed the dependence of some parasites to the population size. For example, measles virus is unable to be maintained in a population less than 250,000 people. After his studies, important aspects concerning vaccine strategies were developed to present day populations.

Barret and colleagues proposed three main epidemiological transitions during human history9. The first was the transition from Paleolithic hunter-gathering subsistence to Neolithic, with agriculture and animal domestication and sedentary habits dominating the scenario, thus facilitating parasite transmission. Next, industrial revolution modified relationships, and chronic diseases began to substitute infectious diseases.

Among small groups of hunter-gatherers in the African savannah, only some species of parasites were able to infect these hosts living in a nomadic way, without establishing themselves in a permanent area. Two species of parasites can be used as examples: the nematode Enterobius vermicularis and the head lice Pediculus humanus. Close related species of these parasites are found in close related hosts to humans, such as chimpanzee and gorilla, indicating that they have shared a common host ancestor. This is the aphorism that Cockburn ${ }^{6}$ called attention to: "like hosts have like parasites". Hermann von Ihering created in 1891 this concept while comparing hosts and parasites of New Zealand and South America to establish ancient relations between them. He stated that when a species diverges into separate groups that eventually become species themselves, the parasites from the original ancestor are passed to all its descendants ${ }^{6}$.

Enterobius vermicularis and Pediculus humanus can be transmitted directly from one individual to another, with no need of a stage in the soil. Therefore, they are not influenced by environmental changes. These parasites are found in either small or large groups of people, inhabiting from very cold regions or tropical warm climates. They are called heirloom parasites and have accompanied humans to all the continents they have conquered and were established.

Other parasites were also originated in African human ancestors of Homo sapiens, evolving together and following human prehistoric migrations to other parts of all the continents. Some of these parasites need special environmental conditions to complete their life cycles. For example, hookworms and Trichuris trichiura are two intestinal parasites that probably originated in African human ancestors. They are transmitted from one host to another after maturating on the soil under limited climate conditions. Eggs or larvae passing with host faeces need $\mathrm{pH}$, humidity and a temperature close to $22^{\circ} \mathrm{C}$ in the soil to reach infective stage and infect another individual. Therefore, these are examples of parasites that have accompanied ancient human migrations from Africa to Europe and Asia, but whenever environmental conditions have hampered the parasite life cycle, the transmission was ceased. Some parasites, therefore, are considered as probes to trace human prehistoric migrations?

\section{Paleoparasitology and the evolution of human parasites}

To recover and trace the origin and evolution of parasitic diseases a new field of research was created, called paleoparasitology. Paleoparasitology is the study of parasites in ancient material ${ }^{2}$. Through the analysis of archaeological and paleontological remains, parasites may be found and identified, mostly at species level. Therefore, it is possible to 
determine infections in space and time, and follow human migrations by the finding of parasites in the archaeological sites that humans occupied in the past.

The analysis of coprolites, or preserved faeces found in archaeological sites or recovered from inside human mummified bodies, is the main source for intestinal helminths. Combining food remains with paleoparasitology analysis also contributes to better understand life in the past ${ }^{10}$. It is possible to recover ancient diet associated with parasite infection or vice-versa. For example, the finding of eggs of a parasite of lizards in human faeces indicated that humans used these animals 10,000 years ago as protein source in the Brazilian northeast ${ }^{11}$.

The record of human tapeworm eggs in coprolites is very scarce $^{12}$. Bruschi and colleagues found a cysticercosis case in an Egyptian mummy dated to the Ptolemaic period (200 to 100 years B.C. $)^{13}$ and Bruschi speculates about the possible neurocysticercosis in Julius Caesar (100 to 44 B.C.) to explain his epilepsy episodes ${ }^{14}$. Other findings in ancient Egypt dated of the Christian period, but it was impossible to determine the species of tapeworm only by the eggs found associated with skeletons. Phylogenetic analysis showed that human parasitism by Taenia solium and Taenia saginata predates the domestication of pigs and cattle ${ }^{15}$. But still there are new perspectives to clarify human relationships with the tapeworm species of cattle or pig.

Ascaris lumbricoides is another intestinal parasite of humans that has a long history of association. Roundworm eggs were found in organic remains dated of 30,000 years before present $(\mathrm{BP})^{16}$, but it was impossible to assert whether of human or other animal origin. There was a debate about roundworm origin, if the human species, Ascaris lumbricoides, originated from the parasite of pigs, Ascaris suum, or viceversa. This should have occurred at 10,000 years ago, after pig domestication.

The techniques of molecular biology were able to evidence that Ascaris lumbricoides infection was commonly found in prehistoric groups, both in North America as in South America ${ }^{17}$, despite the rare findings by microscopy in coprolites collected from New World archaeological sites ${ }^{12}$. Due to the fact that New world wild pigs are not phylogenetic close related to Sus scrofa, and are not parasitized by roundworms, prehistoric human migrants should have brought the parasite from the Old World to the American continent.

When comparing morphologic and genetic characteristics of both species of roundworm, there are few differences between them. This was based on haplotypes that are supposedly found in ascarids of humans and others in pigs. However, these same haplotypes were identified indistinctly in humans and pigs ${ }^{18}$. Therefore, Leles and colleagues proposed that Ascaris lumbricoides is the oldest species that was transferred to pigs after domestication ${ }^{19}$. They conclude that there is a single parasite species of humans and pigs.

\section{Intestinal helminths and the contrast between the} old world and new world

Most of the nematodes that infect the human intestinal tract and were inherited from human ancestors were found in prehistoric populations of the Americas. The first migrants that came to the continent introduced them ${ }^{7}$. However, there are two points to consider: first, not all intestinal helminths were introduced by the same prehistoric route; second, the condition of transmission that these helminths found in the Americas were completely different to those prevalent in Europe ${ }^{8}$.

Although Enterobius vermicularis has no environmental restrictions to hamper transmission from one host to another, other intestinal helminths, as commented above, could not survive in the cold conditions of the Siberian-Arctic regions while prehistoric migrants crossed the Bering land bridge $^{7}$. Hookworms, Trichuris trichiura and Ascaris lumbricoides, found in archaeological sites both in North America and South America, dated as old as 9,000 years ago ${ }^{7,12,20}$. The parasites were introduced by alternative routes, such as transpacific or coastal navigation ${ }^{7}$.

Paleoparasitological data showed that they were prevalent among prehistoric populations in the Americas. However, the eggs found in the coprolites were always low numbered, indicating low prevalence ${ }^{17}$. This is not surprisingly, as most of prehistoric populations in the Americas were nomad and had hunter gathering subsistence for living. However, when Europeans arrived, they established new conditions as colonizers, building villages, slaving Native Americans and later bringing Africans, changing drastically the way of life in the Americas.

It is interesting to compare paleoparasitological data in Mediaeval Europe and prehistoric times in the Americas, before and after Europeans arrived in the New World. While latrines and mummies in Europe are found full of intestinal worms ${ }^{21}$, in the Americas the frame was different: intestinal helminth eggs are very rare in the samples examined ${ }^{12}$, although positive for the same helminths. This should be consequence of differences in the demographic density of both populations, but also as resulting from different occupational patterns of the space. When the first villages were established environment changed as well as the way of life for many people. There was an explosion of soil-transmitted helminths (geohelminths) caused by very poor sanitation conditions and the growing of population $^{8}$.

The study of diseases in ancient populations changed completely a series of misunderstandings about the presence or absence of infectious diseases in prehistory of the Americas. For example, tuberculosis was evidenced in prehistorical groups in North and South America ${ }^{22}$, as well as syphilis was diagnosed by lesions in skeletons and by recovering ancient DNA of the treponema ${ }^{23}$. All the intestinal helminth 
infections, once considered to have been introduced by African slaves, already existed in prehistoric populations ${ }^{12}$.

Paleoparasitology changed the common knowledge based on reports and interpretations of $19^{\text {th }}$ century studious. Paleoepidemiology began to be understood based on solid data by the finding of lesions in skeletons and mummies by the parasites found in archaeological material, and by the recover of parasite ancient DNA ${ }^{17}$.

\section{The example of an old disease in the Americas}

Chagas disease is an example of how paleoparasitology is able to change paradigms. Trypanosoma cruzi infection in humans was believed to have its origin after Andean prehistoric groups in the Bolivian highlands adopted sedentary habits. This was coincident with the domestication of small rodents (guinea pigs, Cavia porcella) raised inside the dwellings, which attracted blood-sucking insects of the subfamily Triatominae, especially of the species Triatoma infestans (family Reduviidae, order Hemiptera). These are vectors of Trypanosoma cruzi, and adopted human dwellings to live. Therefore, Chagas disease was supposed to spread among Andean populations near 6,000 years ago and the infection was only disseminated to other parts of South America after Portuguese colonizers introduced mud and daub dwellings, to which Triatoma infestans adapted ${ }^{24}$.

Paleoparasitology data changed completely the history about the origin of Chagas disease. Aufderheide and colleagues found positive samples by recovering ancient DNA of Trypanosoma cruzi from Chilean skeletons and mummies dated of more than 9,000 years ago ${ }^{25}$, long before domestication of guinea pigs. Reinhard and colleagues described a typical case of Chagas disease megacolon in a mummified body dated of 1,200 years in North America ${ }^{26}$. Fernandes and colleagues did the same in a partially mummified body in Minas Gerais, Central Brazil27, including PCR positive analysis. Lima and colleagues found a positive sample by PCR analysis dated of 7,000 years ago also in Minas Gerais, Central Brazil28. Therefore, Chagas disease was infecting and causing disease in humans long before the domestication of animals, and probably is as old as the presence of humans in any part of the Americas where vectors and wild animal reservoirs were present $^{24}$.

\section{Current research in a multidisciplinary team}

A current research is being developed by a multidisciplinary team in Europe and the Americas about the origin and evolution of Leishmania sp. infection ${ }^{29}$, and Arriaza and colleagues are investigating Pediculus humanus infestation in ancient populations in the coast of Chile ${ }^{30}$. Although it is in its beginning, another research line is the study of parasites found in extinct hosts. This may open phylogenetic approaches from the fossil record to current days. Finding of helminth eggs in dinosaur and related species coprolites began to call attention of paleoparasitologists opening an interesting line of studying the origin and evolution of infectious diseases ${ }^{31}$.

All these studies would be impossible to be developed in a single laboratory. Therefore, paleoparasitology is essentially a multidisciplinary research, stimulating international cooperation for testing hypothesis and redoing tests until trustful results were obtained. Not only paleoparasitologists and archaeologists are involved, but also many other specialists contribute to the understanding of the origin and evolution of infectious diseases.

\section{References}

1. Araujo A, Jansen AM, Bouchet F, Reinhard K, Ferreira LF. Parasites, the diversity of life, and paleoparasitology. Mem Inst Oswaldo Cruz 2003:98(Suppl 1):S5-S11.

2. Ferreira LF, Araújo A. Parasitismo, doença parasitária e paleoparasitologia. In: Coura JR (Ed.), Dinâmica das Doenças Infecciosas e Parasitárias. Segunda edição, Vol. 1, Ed. Gen Guanabara Koogan Rio de Janeiro, 2013:23-33.

3. Ferreira LF. O fenômeno parasitismo. Rev Soc Bras Med Trop 1973;4:261-277.

4. Barrow Jr JH, Stockton JJ. The influences of temperature on the hostparasite relationships of several species of snakes infected with Entamoeba invadens. J Protozool 1960;7:377-383.

5. Cockburn TA. The evolution and eradication of infectious diseases. Baltimore, Johns Hopkins Press, 1963.

6. Cockburn TA. Where did our diseases come from? The evolution of infectious disease. Health and disease in tribal societies. Ciba Foundation Symposium 1977;49:103-113.

7. Araujo A, Reinhard K, Ferreira LF, Gardner S. Parasites as probes for prehistoric migrations? Trends Parasitol 2008;24:112-115.
Reinhard K, Ferreira LF, Bouchet F, et al. Food, parasites, and epidemiological transitions: a broad perspective. Int J Paleopathol 2013;86:1-8.

9. Barrett R, Kuzawa CW, McDade T, Armelagos GJ. Emerging and reemerging infectious diseases: the third epidemiologic transition. Ann Rev Anthropol 1998;27: 247-271.

10. Chaves SAM, Reinhard K. Critical analysis of coprolite evidence of medicinal plant use, Piauí, Brazil. Palaeogeogr Palaeoclimatol Palaeoecol 2006;237:110-118.

11. Sianto L, Santos IT, Chame M, Chaves SAM, Souza SMFM, Ferreira LF, Reinhard K, Araujo A. Eating lizards: a millenary habit evidenced by Paleoparasitology. BMC Res Notes 2012;5:586.

12. Gonçalves MLC, Araujo A, Ferreira LF. Human intestinal parasites in the past: new findings and a review. Mem Inst Oswaldo Cruz 2003;98 (Suppl 1):103-118.

13. Bruschi F, Masetti M, Locci MT, Ciranni R, Fornaciari G. Cysticercosis in an Egytian mummy of the Ptolomaic period. Am J Med Hyg 2006;74:598-599.

14. Bruschi F. Was Julius Caeser's epilepsy due to neurocysticercosis? Trends Parasitol 2011;27:373-374. 
15. Hoberg EP. Phylogeny of Taenia: species definitions and origins of human parasites. Parasitol Int 2006;55(Suppl):S23-S30.

16. Bouchet F, Baffier D, Girard M, Morel P, Paicheler JC, David F. Paléoparasitologie en contexte pléistocène: premières observations à la Grande Grotte d'Arcy-sur-Cure (Yonne), France. CR Acad Sci Paris 1996;319:147-151.

17. Leles D, Reinhard K, Fugassa M, Ferreira LF, Iniguez AM, Araújo A. A parasitological paradox: why is ascarid infection so rare in the prehistoric Americas? J Archaeol Sci 2010;37:1510-1520.

18. Peng W, Yuan K, Hu M, Zhou X, Gasser RB. Mutation scanning-coupled analysis of haplotypic variability in mitochondrial DNA regions reveals low gene flow between human and porcine Ascaris in endemic regions of China. Electrophoresis 2005;26:4317-4326.

19. Leles D, Gardner SL, Reinhard K, Iñiguez A, Araujo A. Are Ascaris lumbricoides and Ascaris suum a single species? Parasit Vect 2012;5:42.

20. Jiménez AF, Gardner SL, Araujo A, et al. Zoonotic and human parasites of inhabitants of Cueva de los Muertos Chiquitos, Rio Zape Valey, Durango, Mexico. J Parasitol 2012;98:304-309.

21. Rocha GC, Harter S, Le Bailly M, et al. Paleoparasitological remains revealed by seven historic contexts from Place d Armes, Namur, Belgium. Mem Inst Oswaldo Cruz 2006;101(Suppl 2): S43-S52.

22. Wilbur AK, Buikstra JE. Patterns of tuberculosis in the Americas: how can modern biomedicine inform the ancient past? Mem Inst Oswaldo Cruz 2006;101(Suppl 2):S59-S66.

23. Harper KN, Zuckerman MK, Harper ML, Kingston JD, Armelagos
GJ. The origin and antiquity of syphilis revisited: an appraisal of Old World pre-Columbian evidence for treponemal infection. Am J Phys Anthropol 2011;146(Suppl 53):S99-S133.

24. Araújo A, Jansen AM, Reinhard K, Ferreira LF. Paleoparasitology of Chagas disease: a review. Mem Inst Oswaldo Cruz 2009;104 (Suppl):S9-S16.

25. Aufderheide AC, Salo W, Madden M, et al. A 9,000-year record of Chagas' disease. Proc Natl Acadf Sci USA 2004;101:2034-2039.

26. Reinhard K, Fink TM, Skiles J. A case of megacolon in Rio Grande Valley as a possible case of Chagas disease. Mem Inst Oswaldo Cruz 2003;98 (Suppl 1):S165-S172.

27. Fernandes A, Iñiguez AM, Lima VS, et al. Pre-Columbian Chagas disease in Brazil: Trypanosoma cruzi I in the archaeological remains of a human in Peruaçu Valley, Minas Gerais, Brazil. Mem Inst Oswaldo Cruz 2008;103:514-516.

28. Lima VS, Iñiguez AM, Otsuki K, et al. Chagas disease by Trypanosoma cruzi lineage I in a hunter-gatherer ancient population in Brazil. Em Infec Dis 2008;14:1001-1002.

29. Khairat R, Ball M, Chang CC, et al. First insights into the metagenome of Egyptian mummies using next-generation sequencing. J App Genetics 2013;Apr 4.[in press].

30. Arriaza B, Orellana N, Barbosa HS, Menna Barreto R, Araujo A, Standen V. Severe head lice infestation in an Andean mummy of Arica, Chile.J Parasitol 2012;98:433-436.

31. Silva PA, Borba V, Dutra J, et al. A new ascarid species in cynodont coprolite dated of 240 million years. An Acad Bras Ci 2014 (in press). 